\title{
EVALUASI IMPLEMENTASI KEBIJAKAN PENDIDIKAN GRATIS DI KABUPATEN PASAMAN
}

\author{
Siti Asyiah \\ Ilmu Administrasi Negara, Fakultas Ilmu Sosial, Universitas Negeri Padang, sitiasyiah@ gmail.com
}

M. Fachri Adnan

Ilmu Administrasi Negara, Fakultas Ilmu Sosial, Universitas Negeri Padang, fachri.adnan@gmail.com

Adil Mubarak

Ilmu Administrasi Negara, Fakultas Ilmu Sosial, Universitas Negeri Padang, adilmubarak@yahoo.co.id

\begin{abstract}
Abstrak
Peraturan Daerah Kabupaten Pasaman Nomor 2 Tahun 2013 mengatur tentang pendidikan gratis yang dilaksanakan di Kabupaten Pasaman. Namun,dalam waktu setelah pelaksanaan pendidikan gratis di Kabupaten Pasaman ditemukan beberapa permasalahan yang tidak sesuai dengan arah kebijakan pendidikan gratis, seperti ditemukannya beberapa sekolah yang meminta pungutan kepada orang tua/siswa untuk membiayai gaji guru honorer.Penelitian ini adalah untuk mengevaluasi implementasi kebijakan pendidikan gratis di Kabupaten Pasaman dan untuk mengevaluasi hasil/capaian implementasi kebijakan pendidikan gratis di Kabupaten Pasaman. Teknik penentuan sampel dilakukan secara purposive sampling.Penelitian dilaksanakan di Dinas Pendidikan dan Kebudayaan Kabupaten Pasaman,SMAN 1 Lubuk Sikaping, SMAN 1 Panti, SMPN 1 Panti dan SDN 09 Petok.Penelitian menggunakan pendekatan kualitatif dengan metode deskriptif. Hasil penelitian menunjukkan bahwa implementasi kebijakan pendidikan gratis di Kabupaten Pasaman cukup baik,dapat dilihat dari komunikasi yang kurang efektif kepada sasaran kebijakan, sumber daya yang tersedia sudah cukup optimal untuk melaksanakan kebijakan, walaupun masih ada kekurangan dalam sumber daya anggaran untuk pengembangan sekolah dan siswa, sikap pelaksana kebijakan cukup baik namun, ada sekolah yang meminta pungutan, dan dalam struktur birokrasi cukup sederhana namun belum memiliki SOP yang jelas. Capaian implementasi kebijakan pendidikan gratis sudah efektiv dan efisien yaitu sudah tercapainya tujuan kebijakan dengan penggunaan dana yang optimal untuk pelaksanaan kebijakan, Kebijakan pendidikan gratis cukup memuaskan kebutuhan masyarakat dalam pendidikan, pelaksanaan pendidikan gratis sudah merata, masyarakat mendukung pelaksanaan pendidikan gratis, Pendidikan Gratis tepat untuk dilaksanakan di Kabupaten Pasaman.
\end{abstract}

Kata Kunci: Evaluasi, Implementasi, Pendidikan Gratis, Pasaman

\begin{abstract}
The Regulation of Pasaman number 2 Year 2013 set about free education in Pasaman. However, in the time after the implementation of the free education in Pasaman found several problems that do not comply with the policy direction of free education, such as the discovery of some schools are asking for charges to parents/students for salary of contract teachers. This research was to evaluate the implementation of free education regulations in Pasaman and to evaluate the results of the implementation of free education regulation in Pasaman. The determination of sample is using purposive sampling technique . Research conducted at the Department of education and culture of Pasaman, SMAN 1 of Lubuk Sikaping, SMAN 1 Panti, SMPN of 1 Panti and SDN 09 Petok. This Research using qualitative approach and descriptive method. The results showed that the implementation of regulation of free education in Pasaman is not good enough, it can be seen from the communication is less effective to policy target, available resources are already quite optimal for carrying out the policy, although there are still deficiencies in budgetary resources for the development of schools and students, the tance of implementor is quite well, however, there are schools that asked for the charges, and in the bureaucratic structure is quite simple but does not have a clear SOP . the result of the implementation of free education regulation objectives already achieved with optimal use of funds and human resources for the implementation of the policy, the policy of free education enough to satisfy the community's needs in education, the implementation of the free education already evenly, the community of Pasaman supports the implementation of free education regulation, the implementation of the free education is right to implemented in Pasaman..
\end{abstract}

Keywords: Evaluation, Implementation, Free Education, Regulation, Pasaman 


\section{PENDAHULUAN}

Pendidikan merupakan salah satu indikator keberhasilan pembangunan suatu negara, hal ini dikarenakan pendidikan merupakan proses dalam membentuk sumber daya manusia yang berkualitas. Pelaksanaan otonomi daerah memberikan kewenangan bagi pemerintah-pemerintah daerah, salah satunya adalah kewenangan dibidang pendidikan. Pelaksanaan program pendidikan gratis di Kabupaten Pasaman, berfungsi untuk memberikan kesempatan yang seluas-luasnya kepada masyarakat usia belajar untuk memperoleh pendidikan.

Pendidikan merupakan salah satu permasalahan yang harus diperhatikan dalam pembangunan nasional. Pembangunan pendidikan adalah proses perombakan struktural subsistem administratif yang berkenaan dengan pengelolaan pendidikan dan subsistem operasional yang berkenaan dengan pengelolaan dengan pendidikan dan pelaksanaan kegiatan belajar mengajar setiap satuan pendidikan agar tercapai tingkat partisipasi, efisiensi, efektivitas, dan relevansi pendidikan yang tinggi (mudyahardjo, 2013: 495-496).

Permasalahan pendidikan di Indonesia menurut Nanang Fattah (2014:29) mencakup beberapa hal seperti: krisis multidimesi termasuk ekonomi mengakibatkan munculnya angkatan kerja yang tidak produktif, mengabaikan relevansi pendidikan dengan perkembangan zaman dan kualitas pendidikan, pendidikan terlalu berorientasi pada input (masukan) dan pola pembangunan yang dilakukan pada sarana-sarana fisik, pemerataan akses untuk memperoleh pendidikan masih rendah (faktor ekonomi, geografis, kultural, gender, dll) dan rendahnya mutu pendidikan dan kualitas pendidikan.

Adanya kebijakan pendiidkan gratis diharapkan dapat meningkatkan tingkat pendidikan masyarakat di Kabupaten Pasaman. Tingkat pendidikan masyarakat di Kabupaten Pasaman masih dapat dikatakan rendah, hal ini dapat dilihat dari data Satkesra Kabupaten Pasaman yang dipublikasikan oleh BPS Kabupaten Pasaman pada Tahun 2015, persentase penduduk desa dan kota di Kabupaten yang memiliki ijazah SMA sederajat hanya sebanyak $16,94 \%$, sementara persentase masyarakat yang tidak memiliki ijazah adalah sebesar 25,92\%.

Berdasarkan data diatas dapat disimpulkan bahwa pelaksanaan kebijakan pendidikan gratis di Kabupaten Pasaman sangat diperlukan. pasal 1 ayat 7 Peraturan Daerah Kabupaten Pasaman Nomor 2 Tahun 2013 dijelaskan bahwa "Pendidikan gratis adalah membebaskan segala biaya pendidikan bagi peserta didik/orang tua peserta didik yang berkaitan dengan proses belajar mengajar dan kegiatan pembangunan sekolah". Penyelenggaran kebijakan pendidikan gratis dimaksudkan untuk meningkatkan taraf pendidikan masyarakat di
Kabupaten Pasaman dalam artian meningkatkan kualitas sumber daya manusianya

penyelenggaraan kebijakan pendidikan gratis selama 12 tahun juga bertujuan untuk meningkatkan angka partisipasi sekolah serta mengurangi angka putus sekolah di Kabupaten Pasaman. Namun,masih ditemukan sejumlah siswa yang putus sekolah. Dikutip dari harian Haluan, yang dipublikasi kan pada tanggal 04 Agustus 2016 lalu bahwa tercatat sebanyak 216 orang siswa SD dan 34 siswa SMP, putus sekolah sepanjang 2015 lalu. Angka ini tersebar di sejumlah kecamatan yang ada di Kabupaten Pasaman.

Pada awal 2017, terjadi pengalihan kewenangan pendidikan SMA sederajat dari Pemerintah Kabupaten ke Pemerintah Provinsi. Kedua permasalahan tersebut menimbulkan keresahan di masyarakat, terutama para orang tua yang memiliki anak yang sekolah di tingkat SMA atau yang akan melanjutkan ketingkat SMA. Pengalihan kewenangan tersebut juga berpengaruh pada penyelenggaraan sekolah berasrama di Kabupaten Pasaman. Terdapat dua sekolah di Kabupaten Pasaman yang menyelenggarakan kelas berasrama. Pengalihan kewenangan pendidikan SMA sederajat ke Provinsi mengakibatkan terkendalanya pelaksanaan kelas unggul berasrama. dikarenakan tidak adanya lagi kewenangan bagi Pemerintahan Daerah untuk mengatur pendanaan Sekolah Menengah Atas sederajat. Sehingga untuk sementara waktu biaya hidup, sewa gedung asrama dan gaji guru pengawas asrama disalah satu sekolah dengan kelas unggu berasrama di bebankan kepada orang tua siswa. Sementara didalam Pasal 10 Peraturan Daerah Nomor 2 Kabupaten Pasaman dikatakan bahwa biaya yang dibebankan kepada orang tua siswa hanya berupa biaya makan dan minum, tidak termasuk diantaranya biaya sewa gedung asrama dan gaji guru pengawas asrama.

Dalam pelaksanaan pendidikan gratis di Kabupaten Pasaman juga ditemui beberapa sekolah yang meminta pungutan liar pada siswa. Seperti dikutip melalui media online www.klikpositif.com , pada 07 Maret 2017, komisi C DPRD Kabupaten Pasaman menerima pengaduan dari wali murid siswa SMA yang disamapaikan oleh wali murid ini yang mengaku resah dengan adanya pungutasn uang SPP dan pembangunan di sekolah, padahal selama ini biaya tersebut sudah gratis dengan adanya program pendidikan gratis di Kabupaten Pasaman. Dari pengakuan wali murid, ada pihak sekolah yyang meminta uang SPP sebesar Rp.75.000 dan uang SPP dan uang pembangunan sebesar Rp.150.000 , dengan alasan untuk membayar guru honor di sekolah tersebut.

Menurut Awal Gusnadi kepala tim pembina dan sekretariat usaha kesehatan sekolah Dinas Pendidikan dan Kebudayaan Kabupaten Pasaman, dalam penyelenggaraan 
pendidikan gratis di Kabupaten Pasaman terdapat permasalahan berasal dari orang tua/wali siswa yaitu kesalahan pemahaman tentang pendidikan gratis tersebut. Orang tua/wali siswa beranggapan bahwa kata "gratis" berarti bahwa orang tua tidak lagi mengeluarkan dana/uang untuk kebutuhan sekolah anaknya termasuk untuk membeli buku sehingga banyak pengaduan mengenai hal tersebut (Awal Gusnadi,17 April 2017)

Kebijakan publik adalah suatu proses formulasi, implementasi dan evaluasi kebijakan yang berkesinambungaan dan saling terkait, yang dilakukan pemeritah dengan stakeholders dalam mengatur mengelola dan menyelesaikan berbagai urusan publik, masalah publik dan sumber daya yang ada untuk kemaslahatan publik (Mulyadi, 2015:3). Danies A. Mazmanian dan Paul A. Sabatier (Abdul Wahab, 2014:65) menyatakan bahwa memahami apa yang nyatanya terjadi sesudah program dinyatakan berlaku atau dirumuskan merupakan fokus perhatian implementasi kebijakan.

Secara khusus evaluasi implementasi menurut Ripley adalah (Herabudin2016:163-164):

1. Melakukan evaluasi terhadap proses,

2. Menambahkan pertanyaan-pertanyaan yang harus dijawab pada perspektif kepatuhan

3. Ditujukan untuk melakukan aspek-aspek dampak kebijakan yang terjadi dalam jangka pendek.

Dwiyanto Indiahono (2009:145), indikator untuk mengevaluasi kebijakan biasanya menunjuk pada dua aspek yaitu aspek proses dan hasil Aspek proses menunjukkan bahwa apakah selama implementasi program,seluruh pedoman kebijakan telah dilakukan secara konsisten oleh implementor dilapangan. Aspek hasil menunjuk apakah kebijakan yang diimplementasikan telah mencapai hasil seperti yang ditetapkan (output dan outcomes).

Berdasarkan pendapat ahli diatas dapat penulis simpulkan bahwa evaluasi implementasi adalah evaluasi terhadap proses implementasi kebijakan dan hasil/pencapaian tujuan kebijakan, dan cara/solusi untuk mengatasi perbedaan antara harapan dan kenyataan.Berdasarkan keterangan diatas evaluasi implementasi dalam penelitian ini dilakukan untuk melihat proses implementasi kebijakan dengan melihat faktor-faktor yang mempengaruhi implementasi kebijakan menurut George C. Edward dan untuk mengevaluasi hasil/capaian kebijakan dengan menggunakan kriteria hasil implementasi menurut William N. Dunn.

Menurut George C. Edward III, dalam Dwiyanto Indiahono (2009:31)terdapat empat (4) indikator yang mempengaruhi impelementasi kebijakan,yaitu:

Komunikasi, dalam konsep George C. Edwards III, komunikasi diterjemahkan sebagai penyampaian pesan/informasi dari pembuat kebijakan kepada pelaksana kebijakan. Dalam bentuk komunikasi demikian, terjadi pengalihan pengetahuan dan pemahaman mengenai kebijakan yang meliputi hakekat kebijakan, cara pelaksanaan, batasan-batasan yang menjadi norma kebijakan, evaluasi terhadap kebijakan. Penelitian oleh Narendra Titis Hardjanti (tahun 2009) ditemukan hasil komunikasi dalam implementasi kebijakan akta kelahiran di Kota Surakarta masih kurang lancar.

Sumber Daya, yaitu menekankan bahwa setiap kebijakan harus didukung oleh sumber daya. Sumber daya adalah segala sesuatu yang dimiliki organisasi untuk mencapai tujuannya.

Hasil penelitian Ratna Yuliana (2015) dari segi sumber daya staf/pegawai pelaksana kebijakan pendidikan gratis sumber daya manusia sudah mencukupi dari segi jumlah serta latar belakang pendidikan. Sumber daya anggaran masih kurang mencukupi.

Disposisi (Sikap Pelaksana),yaitu menekankan terhadap karakteristik yang erat kaitannya dengan karakteristik implementor kebijakan. Kejujuran, komitmen, dan demokratis adalah karakter penting yang harus dimiliki oleh implementor kebijakan.

Penelitian oleh Nurul Laili Hidayati Rizqie (2014) ditemukan bahwa pejabat pelaksana kebijakan sudah siap menjalankan peraturan sesuai dengan isi perda dan sudah memahami isi perda dengan baik.

Struktur Birokrasi,Implementasi kebijakan publik sangat dipengaruhi oleh struktur birokrasi yang terdapat dalam suatu organisasi. Struktur birokrasi terkait dengan karakteristik, norma, dan pola hubungan dalam organisasi untuk melaksanakan kebijakan.

Penelitian oleh Adinda Nurul hikmah (2014) ditemukan hasil dalam implementasi kebijakan penanggulangan bencana di Kota Bekasi belum memiliki SOP.

William N. Dunn (2003:610) memberikan kriteria evaluasi kebijakan secara umum. Karena untuk menilai keberhasilan suatu kebijakan perlu mempertimbangkan beberapa indikator. Karena jika menilai dari satu indikator (indikator tunggal) dapat membahayakan penilaian hasil kebijakan. Ada enam kriteria/indikator penilaian/evaluasi hasil implementasi kebijakan menurut William N. Dunn, yaitu:

Efektivitas, dapat diartikan sebagai ketercapaian tujuan kebijakan setelah kebijakan dilaksanakan.Dalam Penelitian Nurmala Sari Soulisa (2017), ditemukan hasil dapat terlaksananya tujuan dan dirasakannya manfaat dari program dirasakannya manfaat oleh siswa terutama bagi siswa miskin..

Efisensi, adalah keoptimalan penggunaan sumber daya (resources) dalam mencapai tujuan. Efisiemsi juga berkaitan dengan usaha yang diperlukan untuk mencapai 
tujuan kebijakan. Hasil penelitian oleh Nurmala Sari Soulisa (2017:91-98) ditemukan jumlah anggaran dana BOS belum cukup untuk membiayai operasional sekolah.

Kecukupan berkaitan dengan tingkat efektivitas pelaksanaan kebijakan dalam memuaskan kebutuhan.. Kriteria kecukupan berfokus pada kuatnya hubungan antara alternatif kebijakan dan hasil yang diharapkan. Dalam laporan penelitian Nurmala Sari Soulisa (2017:9198) ditemukan bahwa keberadaan dana BOS di sekolah sangat membantu.

Pemerataan/kesamaan, berhubungan dengan keadilan distribusi hasil kebijakan kepada kelompok yang berbeda dalam masyarakat. Kebijakan yang berorientasi pada pemerataan adalah kebijaakan yang akibatn dan usahanya didistribusikan secara adil. Dalam hasil penelitian oleh Ilman Nasution (2016) ditemukan hasil bahwa perataan hasil kebijakan belum terpenuhi.

Responsivitas, dapat diartikan sebagai tanggapan sasaran kebijakan publik terhadap pelaksanaan suatu kebijakan.Hasil penelitian Nurmala Sari Soulisa(2017) ditemukan hasil responsifitas masyarakat cukup baik.

Ketepatan, mengarah pada nilai dari tujuan kebijakan dan kepada kuatnya asumsi yang melandasi tujuan kebijakan tersebut (Dunn, 2003:449). Adinda Nurul hikmah(2014) menemukan ketepatan dalam pelaksanaan kebijakan penanggulangan bencana banjir dinilai cukup baik oleh masyarakat yang berarti pelaksanaan kebijakan yang dilakukan telah cukup tepat dalam memecahkan masalah.

Berdasarkan uraian masalah diatas tujuan penelitian ini adalah untuk mengevaluasi implementasi Peraturan Daerah Kabupaten Pasaman Nomor 2 Tahun 2013 tentang pendidikan gratis. Penelitian ini dilakukan dengan melihat dua aspek dalam evaluasi kebijakan yaitu aspek proses dan aspek hasil. Aspek proses yaitu untuk melihat dan menilai implementasi kebijakan Peraturan Daerah Kabupaten Pasaman Nomor 2 Tahun 2013 tentang Pendidikan Gratis melalui analisis menggunaka teori faktor-faktor yang mempengaruhi implementasi kebijakan menurut George C. Edward III. Aspek hasil/capaian yaitu untuk melihat dan menilai implementasi kebijakan Peraturan Daerah Kabupaten Pasaman Nomor 2 Tahun 2013 tentang Pendidikan Gratis melalui analisi menggunakan teori evaluasi hasil kebijakan menurut William N.Dunn.

\section{METODE}

Jenis penelitian ini adalah kualitaif deskriptif. Penelitian dilakukan di Kabupaten Pasaman dengan subjek penelitian yaitu implementasi Peraturan Daerah Kabupaten Pasaman Nomor 2 Tahun 2013 tentang pendidikan gratis. yaitu di badan/dinas yang berwenang dalam penyelenggaraan dan pelaksanaan program pendidikan gratis 12 (dua belas) tahun di Kabupaten Pasaman antara lain Dinas Pendidikan dan Kebudayaan Kabupaten Pasaman, SMAN 1 Lubuk Sikaping, SMAN 1 Panti, SDN 09 Petok, serta di lingkungan masyarakat yang menjadi sasaran dari implementasi Perda/program tersebut yaitu orang tua/wali siswa.

Sumber data primer penelitian ini diperoleh langsung dari informan penelitian.Penelitian awal yang telah dilakukan yakni tanggal 17 April 2017 instansi terkait yaitu Dinas Pendidikan dan Kebudayaan Kabupaten Pasaman dan pada masyarakat sasaran. Observasi ini dilakukan untuk mengetahui kondisi pelaksanaan pendidikan gratis di Kabupaten Pasaman. Penelitian berlanjut pada tanggal 18 April 2017di sekitar Kampung Harapan Maju(bombay) Nagari Panti Selatan, Kecamatan Panti, Kabupaten Pasaman. Pada observasi ini dengan melihat objek penelitian pada permasalahan dan pelanggaran yang terjadi dalam pelaksanaan pendidikan gratis di Kabupaten Pasaman.Penelitian kembali dilakukan kembali dari Oktober-November 2017, observasi ketiga ini kegiatan difokuskan pada penyesuaian hasil wawancara yang sudah didapatkan sebelumnya dengan fakta dilapangan berdasarkan hasil observasi. Observasi dilakukan secara terstruktur dan sistematik diawali dari objek yang akan diteliti sampai pada informan yang telah diwawancarai.

Dalam penelitian ini penulis menggunakan teknik triangulasi data yaitu dengan mempergunakan berbagai sumber data atau informasi.

\section{HASIL DAN PEMBAHASAN \\ Evaluasi Proses Implementasi Kebijakan Pendidikan Gratis}

George C. Edward III (Indiahono, 2009:31) menyatakan bahwa ada empat variabel yang mempengaruhi keberhasilan implementasi kebijakan yaitu: komunikasi, sumberdaya,disposisi dan struktur birokrasi. Pertama adalah faktor komunikasi, pelaksanaan komunikasi yang dilakukan oleh organisasi pelaksana kebijakan pendidikan gratis di Kabupaten Pasaman yaitu Dinas Pendidikan dan Kebudayaan Kabupaten Pasaman dan sekolah cukup baik namun masih kurang efektif. hasil wawancara dengan masyarakat, ditemukan bahwa masih ada masyarakat yang tidak tahu mengenai kebijakan pendidikan gratis. Masyarakat mengetahui pelaksanaan pendidikan gratis di Kabupaten Pasaman karena tidak ada lagi uang sekolah yang harus dibayarkan perbulan untuk tingkat SMA-sederajat, sementara untuk tingkat Pendidikan Dasar (SMP/SD-sederajat)masih banyak masyarakat yang tidak mengetahui kebijakan ini sehingga ada beberapa sekolah yang meminta pungutan kepada 
siswa/orang tua siswa dengan alasan untuk pembangunan sekolah. Seperti membangun WC dan pustaka/ penyediaan buku pustaka.

Dalam Pasal 10 Perda Kabupaten Pasaman Nomor 2 tahun 2013 disebutkan bahwa: "Komite Sekolah, Kepala Sekolah dan/atau guru dilarang melakukan pungutan dalam bentuk apapun dan sekecil apapun kepada orang tua peserta didik kecuali dalam hal: a. Biaya makan minum siswa pada sekolah unggul yang tinggal di asrama, sesuai ketentuan standar biaya makan minum yang ditetapkan". Berdasarkan isi pasal tersebut dapat dilihat bahwa setelah dilaksanakannya Pendidikan gratis di Kabupaten Pasaman, sekolah dilarang untuk memungut biaya dalam bentuk apapun, kecuali untuk biaya makan dan minum siswa pada sekolah unggul yang tinggal di asrama. Sementara dalam hasil wawancara penulis dengan masyarakat ditemukan bahwa ada beberapa sekolah yang meminta pungutan kepada masyarakat. Berdasarkan fakta tersebut dapat dilihat bahwa komunikasi kebijakan pendidikan gratis di Kabupaten Pasaman masih kurang efektif.

Menurut George C. Edward III, komunikasi menjadi sangat penting dalam implementasi kebijakan untuk mengurangi penolakan dan kesalahan pemahaman dalam pelaksanaan program dan kebijakan (Indiahono, 2009:31). Berdasarkan hasil penelitian Narendra Titis Hardjanti (2009) dan penelitian penulis dapat disimpulkan bahwa, komunikasi dalam implementasi kebijakan berdampak pada kemampuan masyarakat dalam memahami isi kebijakan. Masyarakat sebagai sasaran kebijakan harus mengetahui kebijakan sehingga masyarakat dapat mengawasi kesesuaian pelaksanaan kebijakan dengan peraturan/kebijakan yang sudah ada.

Kedua sumber daya, dalam Implementasi kebijakan pendidikan gratis di Kabupaten Pasaman ditemukan bahwa sumber daya manusia dalam organisasi pelaksana dan sumber daya anggaran (modal/dana) dalam implementasi kebijakan pendidikan gratis di Kabupaten Pasaman sudah cukup memadai. Sumber daya manusia dalam implementasi kebijakan pendidikan gratis dapat dilihat dari organisasi pelaksana yaitu Dinas Pendidikan dan Kebudayaan Kabupaten Pasaman dan sekolahsekolah yang ada di Kabupaten Pasaman. Sumber daya manusia/organisasi pelaksanaan pendidikan gratis di Kabupaten Pasaman yaitu:

Dinas Pendidikan dan Kebudayaan Kabupaten Pasaman bertanggung jawab dalam menyelenggarakan urusan pemerintah di bidang pendidikan dan bidang kebudayaan. Dalam pelaksanaan pendidikan gratis di Kabupaten Pasaman terdapat beberapa bagian yang bertugas untuk melaksanakan proses administrasi maupun hal lainnya, diantaranya yaitu Kepala Dinas, Bagiam Umum, Bagian Keuangan, Bagian Sekretariat dan
Program, Bagian Keuangan,dan Bidang Pendidikan Dasar.

Tabel 1: Jumlah Pegawai Disdikbud Kabupaten Pasaman berdasarkan tingkat pendidikan

\begin{tabular}{clccc}
\hline \multirow{5}{*}{ No } & \multicolumn{4}{c}{ Jumlah pegawai menurut } \\
\cline { 2 - 5 } Tingkat pendidikan & Jumlah & Golongan & Jumlah \\
\hline 1 & SD & 1 & I & \\
2 & SMP/paket B & 1 & II & 7 \\
3 & SMA/SMK/MA/paket C & 8 & III & 36 \\
4 & D3 & 3 & IV & 22 \\
5 & S1 & 45 & & \\
6 & S2 & 7 & & \\
\hline & Jumlah & $\mathbf{6 5}$ & $\mathbf{6 5}$ \\
\hline
\end{tabular}

Sumber: Dinas Pendidikan dan Kebudayaan Kabupaten Pasaman

Dari data tersebut dapat dilihat bahwa sumber daya manuasi yang ada di Dinas Pendidikan dan Kebudayaan Kabupaten Pasaman dalam pelaksanaan kebijakan pendidikan gratis sudah cukup memadai dari segi kuantitas dan sudah cukup baik dari segi kualitas yang dapat dillihat dari latar belakang pendidikan pegawai.

Sekolah adalah tempat bagi peserta didik untuk memperoleh pendidikan.Mengajari, mengelola dan mendidik peserta didik melalui bimbingan melalui tenaga pendidik adalah tujuan dibentuknya sekolah. Dalam pelaksanaan pendidikan gratis sumber daya manusia di sekolah diantaranya yaitu, seluruh perangkat sekolah, seperti Kepala Sekolah, komite sekolah, guru,dan tata usaha.

Sumber daya anggaran dalam implementasi kebijakan pendidikan gratis di Kabupaten Pasaman sudah mencukupi untuk melaksanakan pendidikan. Namun untuk kegiatan pengembangan siswa dan sekolah masih kurang mencukupi.

Tabel 2: Anggaran Pendidikan Gratis

\begin{tabular}{cccc}
\hline No & Tahun & Jumlah Anggaran & Tingkat Sekolah \\
\hline 3 & 2016 & Rp.11.032.700.000, & SD,SMP,SMA,SMK(Negeri) \\
4 & 2017 & Rp.5.863.110.000, & SD dan SMP(Negeri) \\
\hline
\end{tabular}

Sumber : Dinas Pendidikan dan Kebudayaan Kabupaten Pasaman

Anggaran dana pelaksanaan kebijakan pendidikan gratis berasal dari dana APBD yang disebut dana BOSDA. Dari hasil wawancara dengan informan peneletian yang berperan sebagai pelaksana kebijakan disimpulkan bahwa dana yang tersedia sudah cukup untuk melaksanakan proses pendidikan disekolah. Kekurangan terjadi dalam pelaksanaan kegiatan pengembangan sekolah dan siswa.

Sumber daya adalah segala sesuatu yang dimiliki organisasi untuk melaksanakan kebijakan. Sumber daya 
yang memadai baik fisik (sumber daya manusia, sarana dan prasarana, dll) maupun modal/anggaran sangat diperlukan dalam implementasi kebijakan. Sumber daya manusia ketersediaan pelaksana kebijakan baik kualitas maupun kuantitas. Sumber daya finansial adalah kecukupan modal/anggaran untuk mendukung pelaksanaan program/kebijakan.

Berdasarkan hasil penelitian Ratna Yuliana (2015) dan penelitian penulis dapat disimpulkan bahwa faktor sumber daya berpengaruh terhadap implementasi kebijakan. Dalam penelitian oleh Ratna Yuliana (2015) dan Penelitian penulis sumber daya manusia dan sumber daya modal/anggaran merupakan 2 (dua) sumber daya yang perlu diperhatikan dalam implementasi kebijakan.

Ketiga, sikap pelaksana dalam pelaksanaan pendidikan gratis di Kabupaten Pasaman, yaitu Dinas Pendidikan dan Kebudayaan Kabupaten Pasaman dan sekolah yang menyelenggarakan pendidikan gratis di Kabupaten Pasaman sudah cukup baik. Terlihat dari komitmen pelaksana dalam menjalankan pendidikan, meskipun dari hasil wawancara dengan masyarakat, masih ditemukan sekolah yang tidak melakukan kebijakan pendidikan gratis sesuai dengan ketentuan dalam peraturan yang telah ditetapkan.

disposisi adalah sikap pelaksana dalam melaksanakan kebijakan. Karakter yang penting dimiliki oleh implementor adalah kejujuran, komitmen, dan demokratis. Pada dasarnya sikap (disposition) melekat pada kepribadian pada pembuat kebijakan dan pelaksana kebijakan dalam bentuk perbuatan dan sebagainya yang berdasarkaan pada pendirian, keyakinan. Sikap merupakan kondisi mental yang melibatkan keyakinan dan perasaan.

Implementor yang memiliki komitmen tinggi dan jujur akan senantiasa bertahan diantara hambatan yang ditemui dalam program/kebijakan. Kejujuran mengarahkan implementor untuk tetap berada dalam arah program yang telah digariskan dalam guideline program. Komitmen dan kejujuran membawanya semakin antusias dalam melaksanakan tahap-tahap program secara konsisten. Sikap yang demokratis akan meningkatkan kesan baik implementor dan kebijakan dihadapan anggota kelompok sasaran. Sikap ini akan menurunkan resistensi dari masyarakat dan menumbuhkan rasa percaya dan kepedulian kelompok sasaran terhadap implementor program/kebijakan (Indiahono, 2009:32).

Berdasarkan hasil penelitian oleh Nurul Laili Hidayari Rizqie (2014) dan penelitian yang penulis lakukan dapat disimpulkan bahwa sikap pelaksana dalam implementasi kebijakan berpengaruh terhadap implementasi kebijakan. Sikap pelaksana dalam penelitian oleh Nurul Laili Hidayati Rizqie dan penelitian penulis dapat dinilai melalui komitmen pelaksana/implementor untuk melaksanakan kebijakan, sesuai dengan peraturan atau ketentuan yang sudah ditetapkan dalam kebijakan.

Keempat struktur organisasi, hasil penelitian penulis ditemukan bahwa dalam pelaksanaan kebijakan pendidikan gratis struktur organisasi tidak berbelit-belit dan tidak terlalu menyulitkan sekolah selaku pelaksana. Namun permasalahan dalam struktur birokrasi adalah tidak adanya SOP yang jelas dalam pelaksanaan kebijakan pendidikan gratis.

Struktur birokrasi merupakan satu variabel penting dalam implementasi kebijakan.Struktur birokrasi mencakup dua hal penting yaitu mekanisme dan struktur organisasi pelaksana. Dwiyanto Indiahono (2009:32) "Mekanisme/ tata cara pelaksanaan suatu kebijakan bisanya sudah dijelaskan dalam standar operating procedur (SOP) yang dicantumkan dalam guideline program/kebijakan". Berdasarkan hasil penelitian oleh Adinda Nurul Hikmah (2014) dan hasil penelitian penulis dapat disimpulkan bahwa salah satu indikator dalam struktur birokrasi pelaksanaan kebijakan adalah Standar Operasional Prosedur (SOP). SOP dianggap penting karena merupakan panduan dalam melakukan kegiatan atau pekerjaan dalam suatu organisasi.

\section{Evaluasi Hasil Implementasi Kebijakan Pendidikan Gratis}

Menurut William N. Dunn (2003:610) ada enam kriteria yang digunakan untuk mengevaluasi hasil pelaksanaan kebijakan, yaitu:

Pertama: efektivitas, Pasal 5 Peraturan Daerah Kabupaten Pasaman Nomor 2 tahun 2013 tentang pendidikan gratis disebutkan bahwa "pendidikan gratis bertujuan untuk mengurangi beban masyarakat, peserta didik/orang tua peserta didik." Hasil penelitian yang penulis lakukan efektivitas pelaksanaan pendidikan gratis sudah cukup baik. Hal ini dapat dilihat dari hasil wawancara dengan masyarakat yang banyak menyatakan bahwa masyarakat merasa terbantu dengan pelaksanaan pendidikan gratis, karena tidak perlu lagi membayar uang sekolah.

Menurut Willian N. Dunn, efektivitas selalu terkait dengan hubungan antara hasil yang diharapkan dengan hasil yang telah dicapai. Hasil penelitian ini pada dasarnya mendukung penelitian oleh Nurmala Sari (2017). Dari hasil penelitian Nurmala Sari Soulisa dan penelitian yang penulis lakukan dapat disimpulkan bahwa, hasil implementasi kebijakan dapat dikatakan efektif apabila tujuan dari kebijakan tersebut.

Kedua: efisiensi, tujuan dilaksanakannya pendidikan gratis adalah untuk membantu meringankan orang tua siswa dalam membiayai pendidikan anaknya. Fungsi kebijakan pendidikan gratis dalam Pasal 4 Perda Kabupaten Pasaman No.2 adalah untuk "memberikan 
kesempatan yang seluas-luasnya kepada usia belajar untuk mendapatkan pendidikan yang layak dan bermutu”. Hasil penelitian yang penulis lakukakan, penggunaan dana pendidikan gratis sudah mencukupi untuk menunjang pelaksanaan standart minimal pendidikan di sekolah. Kekurangan terjadi dalam kegiatan pengembangan sekolah, kegiatan ekstrakulikuler serta untuk biaya siswa dalam mengikuti perlombaan.

Efisiensi dalam implementasi kebijakan berkenaan dengan jumlah usaha yang diperlukan untuk memcapai tujuan kebijakan. Efisiensi juga berkenaan dengan keoptimalan sumber daya untuk mengusahakan tercapainya tujuan kebijakan.

Hasil penelitian Nurmala Sari Soulisa dan penelitian penulis dapat disimpulkan bahwa jumlah sumber daya dan usaha yang optimal. Jika tidak tersedia sumber daya yang optimal maka implementasi kebijakan akan terkendala dan bisa jadi tujuan kebijakan tidak dapat dicapai.

Ketiga: kecukupan, pelaksanaan pendidikan gratis di Kabupaten Pasaman sudah cukup memuaskan kebutuhan masyarakat dalam pendidikan. Berdasarkan wawancara yang penulis lakukan dengan masyarakat pendidikan merupakan suatu kebutuhan. Pendidikan gratis membebaskan segala biaya pendidikan yang sebelumnya ditanggung oleh orang tua siswa, sehingga dapat disimpulkan bahwa pendidikan gratis sudah dapat mencukupi kebutuhan masyarakat Kabupaten Pasaman dalam pendidikan. Hal ini dikarenakan pendidikan gratis memberikan kesempatan kepada usia belajar untuk mendapatkan pendidikan seluas-luasnya dengan membebaskan biaya pendidikan.

Kecukupan berkenaan dengan pengukuran seberapa jauh kebijakan yang ada dapat memuaskan kebutuhan masyarakat. Kebijakan pendidikan gratis dilaksanakan untuk memuaskan kebutuhan masyarakat terhadap pendidikan.

Berdasarkan hasil penelitian oleh Nurmala Sari Soulisa (2017:91-98) dan penelitian ini dapat dilihat bahwa, kecukupan hasil implementasi kebijakan dapat dilihat dari kebermanfaatan kebijakan dalam mengurangi/menyelesaikan masalah yang ada di masyrakat/sasaran kebijakan.

Keempat: pemerataan, dalam Peraturan Daerah Kabupaten Pasaman Nomor 2 tahun 2013 dinyatakan salah satu fungsi pendidikan gratis adalah "memberikan kesempatan yang seluas-luasnya kepada usia belajar guna mendapatkan pendidikan yang layak dan bermutu, yang dimaksud memberikan kesempatan yang seluas-luasnya adalah kesempatan untuk memilih sekolah dalam wilayah Kabupaten Pasaman baik negeri maupun swasta tanpa membeda-bedakan masyarakat miskin dan kaya.”
Berdasarkan isi Perda Kabupaten Pasaman No.2 tahun 2013 tentang pendidikan gratis dalam penelitian yang penulis lakukan pelaksanaan pendidikan gratis di Kabupaten Pasaman sudah dilaksankan dengan berorientasi pada pemerataan kebijakan. Karena dalam penganggaran pendidikan gratis didasarkan pada jumlah siswa yang aktif/bersekolah pada waktu penganggaran. Sehingga pelaksanaan pendidikan gratis diselenggarakan dengan merata tanpa membeda-bedakan siswa berdasarkan status ekonomi ataupun hal lainnya.

Pemerataan berkaitan dengan keadilan yang diberikan oleh pelaksana kepada sasaran kebijakan. Kebijakan yang berorientasi pada pemerataan mendistribusikan akibatnya atau usahanya didistribusikan secara adil.

Hasil penelitian penulis dan penelitian oleh Ilman Nasution ditemukan perbedaan. Dalam penelitian oleh Ilman Nasution (2016) ditemukan hasil pemerataan hasil implementasi kebijakan belum cukup baik, karena hanya beberapa orang/pihak saja yang merasakan manfaat dari implementasi kebijakan. Berbeda dengan hasil penelitian Ilman Nasution, hasil implementasi kebijakan pendidikan gratis di Kabupaten Pasaman sudah dirasakan merata oleh sasaran kebijakan, karena dalam pendidikan gratis dirasakan oleh semua siswa yang terdaftar (aktif) di sekolah, tanpa ada perbedaan.

Berdasarkan hasil penelitian oleh Ilman Nasution (2016) dan hasil penelitian ini hasil implementasi kebijakan dapat dikatakan merata apabila, impact/dampak implementasi kebijakan dapat didistribusikan/dirasakan secara merata dan adil kepada pihak yang menjadi sasaran dalam kebijakan.

Kelima: responivitas, berdasarkan penelitian yang penulis lakukan,tanggapan sasaran terhadap pelaksanaan kebijakan pendidikan gratis sangat baik. Masyarakat sasaran mendukung pelaksanaan pendidikan gratis di Kabupaten Pasaman. Pemindahan kewenangan pendidikan Sekolah Menengah ke Provinsi mengakibatkan diberhentikannya pemberlakuan kebijakan pendidikan gratis untuk tingkat Sekolah Menengah (SMA-sederajat) atas keadaan tersebut masyarakat berharap pelaksanaan pendidikan gratis ini dapat terus dilanjutkan hingga ke tingkat Sekolah Menengah bukan hanya di tingkah Pendidikan Dasar (SMP/SD-sederajat).

Responsivitas dalam implementasi kebijakan (program) publik diartikan sebagai tanggapan sasaran kebijakan publik atas penerapan suatu kebijakan. Keberhasilan kebijakan dapat dilihat melalui tanggapan masyarakat yang menanggapi pelaksanaan setelah terlebih dahulu memprediksi pengaruh yang akan terjadi jika kebijakan akan dilaksanakan, juga tanggapan masyarakat setelah dampak kebijakan sudah 
mulai dapat dirasakan dalam bentuk dukungan/berupa penolakan.

Terdapat kesamaan hasil penelitian oleh Nurmala Sari Soulisa (2017) dan hasil penelitian yang penulis lakukan, yaitu responsivitas masyarakat sasaran yang cukup baik dalam implementasi kebijakan. Hal ini dapat dilihat dari adanya dukungan dan harapan dari masyarakat sasaran terhadap pelaksanaan kebijakan. Berdasarkan temuan tersebut indikator responsivitas dalam evaluasi hasil kebijakan dapat dilihat dari respon sasaran kebijakan.

Keenam: ketepatan, berdasarkan hasil penelitian penulis, pendidikan gratis sudah tepat untuk dilaksanakan di Kabupaten Pasaman. Hal ini dapat dilihat dari rendahnya tingkat pendidikan masyarakat di Kabupaten Pasaman sehingga yang berdampak pada rendahnya kualitas sumber daya manusia di Kabupaten Pasaman. Pendidikan gratis adalah salah satu kebijakan yang dapat meningkatakan kesejahteraan masyarakat melalui pendidikan, sehingga sangat tepat untuk dilaksanakan di Kabupaten Pasaman.

Ketepatan berkaitan dengan kerasionalan kebijakan untuk memenuhi kebutuhan yang dirasa penting oleh publik. Dunn (2003:499) menyatakan bahwa "ketepatan adalah kriteria yang dipakai untuk menseleksi sejumlah alternatif untuk dijadikan rekomendasi dengan menilaiapakah hasil dari alternatif yang direkomendasikan tersebut merupakan pilihan tujuan yang layak dan tepat.”

Berdasarkan hasil penelitian oleh Adinda Nurul Hikmah (2014) dan hasil penelitian penulis dapat disimpulkan bahwa ketepatan dalam hasil implementasi kebijakan dapat dilihat dari ketepatan kebijakan untuk menjadi solusi atas masalah yang yang sedang dihadapi masyarakat.

\section{PENUTUP}

\section{Simpulan}

Implementasi Peraturan Daerah Kabupaten Pasaman No.2 Tahun 2013 tentang pendidikan gratis,Dari segi komunikasi, Komunikasi dalam pelaksanaan pendidikan gratis di Kabupaten Pasaman masih kurang efektif karena masih ada masyarakat yang tidak mengetahui pelaksanaan pendidikan gratis, kebanyakan masyarakat hanya tau dari tidak adanya lagi bayaran bulanan sekolah tanpa tau kebijakannya;Dari segi sumber daya, sumber daya dalam pelaksanaan pendidikan gratis dari segi jumlah dan tingkat pendidikan sudah cukup memadai. Sumber daya anggaran sudah disediakan oleh Pemerintah Daerah, dana pendidikan gratis disebut dengan dana BOSDA.Dari segi disposisi, komitmen pelaksana dalam pelaksanaan pendidikan gratis di Kabupaten Pasaman masih kurang baik, karena masih ada ditemukan sekolah yang meminta iuran/pungutan kepada orang tua siswa. Dari struktur birokrasi, implementasi kebijakan pendidikan gratis di Kabupaten Pasaman belum memiliki SOP yang jelas.

Evaluasi Hasil/Capaian Implementasi Peraturan Daerah Kabupaten Pasaman No.2 Tahun 2013 tentang pendidikan gratis dari segi Efektivitas, tujuan kebijakan sudah dicapai, sehingga implementasi kebijakan pendidikan gratis di Kabupaten Pasaman sudah efektif. Efisiensi,jumlah dana atau anggaran pendidikan gratis sudah cukup optimal untuk mendukung pelaksanaan pendidikan di sekolah. Kekurangan terjadi pada pelaksanaan kegiatan pengembangan siswa dan sekolah. Kecukupan, pelaksanaan pendidikan gratis di Kabupaten Pasaman sudah cukup memuaskan kebutuhan masyarakat akan pendidikan. Pemerataan, pelaksanaan pendidikan gratis sudah dilaksanakan dengan merata dan adil,penganggaran pelaksanaan pendidikan gratis berdasarkan jumlah siswa yang terdaftar aktif disekolah tanpa ada perbedaan. Responsivitas, respon masyarakat sasaran dalam pelaksanaan pendidikan gratis cukup baik, masyarakat mendukung pelaksanaan pendidikan gratis dan mengharapakan pendidikan gratis tetap dilanjutkan. Ketepatan, pendidikan gratis memberikan kesempatan kepada masyarakat sasaran untuk memperoleh pendidikan seluas-luasnya hingga ke tingkat sekolah menengah secara gratis.

Berdasarkan ringkasan diatas dapat disimpulkan bahwa implementasi kebijakan pendidikan gratis masih kurang baik, namun hasil dari implementasi kebijakan sudah baik. Berdasarkan hasil penelitian penulis kurang baiknya proses implementasi disebabkan oleh faktorfaktor yang berasal dari implementor/pelaksana kebijakan sementara baiknya hasil implementasi kebijakan adalah karena substansi kebijakan yang bermanfaat bagi masyarakat dan dapat memenuhi kebutuhan masyarakat terutama dalam hal pendidikan.

\section{Saran}

Berdasarkan pembahasan dan kesimpulan diatas dapat diajukan beberapa saran terkait dengan pelaksanaan pendidikan gratis di Kabupaten Pasaman.Berkaitan dengan implementasi kebijakan pendidikan gratis, diperlukan komunikasi kebijakan yang lebih baik untuk menginformasikan pelaksanaan pendidikan gratis kepada masyarakat sasaran. Agar pelaksanaan pendidikan gratis dapat dilaksanakan sebagaimana seharusnya, pelanggaran dan kesalahpahaman terhadap kebijakan dapat dihindarkan.

Diperlukan komunikasi kebijakan yang lebih berorientasi kepada masyarakat dengan bekerjasama dan koordinasi dengan tokoh masyarakat agar pelaksanaan pendidikan gratis dapat terlaksana dengan lebih merata. 
Diperlukan pengawasan yang lebih baik untuk mengawasi pelaksanaan pendidikan gratis, agar dalam pelaksana pendidikan gratis di Kabupaten Pasaman tidak ditemukan pelanggaran oleh sekolah maupun pihsk lain. Diperlukan sanksi yang jelas untuk pihak-pihak yang melakukan pelanggaran dalm pelaksanaan pendidikan gratis.

Diperlukan kejelasan dalam prosedur (SOP) pelaksanaan pendidikan gratis di Kabupaten Pasaman agar pelaksanaan pendidikan gratis di Kabupaten Pasaman lebih jelas dan transparan. Kerjasama dan koordinasi dengan tokoh masyarakat agar pelaksanaan pendidikan gratis dapat terlaksana dengan lebih merata.

Diperlukan alternatif kebijakan yang mendukung pelaksanaan pendidikan gratis hingga ke tingkat SMA. Kebijakan pendidikan gratis saat ini tidak lagi sampai ke tingkat Sekolah Menengah dikarenakan pemindahan kewenangan pelaksanaan pendidikan ke provinsi. Oleh karena itu, diperlukan alternatif kebijakan yang dapat menjadi landasan untuk pelaksanaan pendidikan gratis hingga ke sekolah menengah.

\section{DAFTAR PUSTAKA}

Dunn, William N.2003 (1994). Public Policy Analysis: An Introduction, New Jersey: Pearson Education. Edisi bahasa Indonesia diterjemahkan dari edisi kedua (1994) diterbitkan sejak 1999 dengan judul Pengantar Analisis Kebijakan Publik. Yogyakarta: Gadjah Mada University Press.

Dwiyanto, indiahono. 2009. Kebijakan Publik Berbasis Dynamic Policy. Yogyakarta: Gava Media.

Herabudin, 2016. Studi Kebijakan Pemerintah. Bandung: Pustaka Setia.

Mudyahardjo, Redja. 2013. Pengantar Pendidikan Sebuah Studi Awal Tentang Dasar-Dasar Pendidikan Pada Umumnya Dan Pendidikan Indonesia. Jakarta: rajawali Press

Mulyadi, Deddy. 2015.Studi Kebijakan Publik dan Pelayanan Publik: Konsep dan Aplikasi Proses Kebijakan Publik dan Pelayanan Publik. Bandung: Alfabeta

Mulyana, Deddy. 2010. Metodologi Penelitian Kualitatif. Bandung: Remaja Rosdakarya.

Fattah, Nanang. 2014. Analisis Kebijakan Pendidikan. Bandung: Remaja Rosdakarya.

Hafid, Anwar, dkk. 2014. Konsep Dasar Ilmu Pendidikan. Bandung:Alfabeta

Nawawi, Ismail. 2009. Public Policy: Analisis, Strategi Advokasi Teori dan Praktek.
Parson, Wayne. 2001. Public Policy: Pengantar Terori dan Praktik Analisis Kebijakan. Jakarta: Prenada Media.

Wahab, Solichin Abdul. 2014. Analisis Kebijakan: Dari Formulasi ke Penyusunan Model-Model Implementasi Kebijakan Publik. Jakarta: Bumi Aksara.

Hikmah, Adinda Nurul, 2014. Evaluasi Implementasi Kebijakan Dalam Penanggulangan Bencana Banjir (Studi Kasus Di Kawasan Perumahan Pondok Gede Permai, Jatiasih, Kota Bekasi Periode 2013-2014). Laporan Penelitian:Universitas Diponegoro.

Nasution, Ilman. 2017. Evaluasi Implementasi Kebijakan Tentang Tatanan Kebandarudaraan Nasional (Studi Pada Bandar Udara Sultan Syarif Kasim II). Laporan Penelitian:Universitas Riau. JOM FISIP, VOL 4 No. 2

Soulisa, Nurmala Sari. 2017. Evaluasi Kebijakan Dana Bantuan Operasional Sekolah (BOS) Pada Sekolah Negeri Di Kecamatan Palu. Jurnal Katalogis. Vol. 5, No.1. Hal:91-98.

Yuliana, Ratna. 2015. Evaluasi Pelaksanaan Kebijakan Pendidikan GratisPada jenjang Sekolah Menengah Di Kabupaten Sukoharjo. Artikel Laporan Penelitian Universitas Diponegoro: Semarang.

Kabupaten Pasaman Dalam Angka. 2016. Badan Pusat Statistik Kabupaten Pasaman.

Peraturan Bupati Pasaman Nomor.34 Tahun 2013 tentang Pelaksanaan Peraturan Daerah Kabupaten Pasaman Nomor 2 Tahun 2013 Tentang Pendidikan Gratis.

Peraturan daerah Nomor.2 Tahun 2013 Kabupaten Pasaman tentang Pendidikan Gratis.

Statistik Kesejahteraan Masyarakat. 2015. Badan Pusat Statistik Kabupaten Pasaman.

Undang-Undang Dasar 1945

Undang-Undang Nomor 32 tahun 2004 Tentang Pemerintahan Daerah

Undang-Undang Nomor 20 tahun 2003 Tentang Sistem Pendidian Nasional

http://www.pasamankab.go.id

http://www.pasamankab.bps.go.id

http://haluan.com

http://klikpositif.com 